\title{
From Ruler to Pariah: The Life and Times of the True Path Party
}

\author{
ÜMİT CİZRE
}

The historical conditions surrounding the birth of the True Path Party (Doğru Yol Partisi-DYP) on June 23, 1983 are identical to the labor pains of its predecessor, the Justice Party (Adalet Partisi-AP), on November 20, 1961. The AP had established itself as the principal heir to the Democratic Party (Demokrat Parti-DP) which was closed down by the 1960 military coup. The military rulers rooted the emergence of both the AP and DYP in the closure of their predecessor parties. More importantly, this time the crisis coincided with the challenges and uncertainties posed by new global trends, a generalized political phenomenon of democratization, and free market economy being the most significant ones. This contribution will consider the life and times of the DYP essentially in terms of the language, method, and logic of its reluctant change over time. ${ }^{1}$

\section{HISTORICAL LUGGAGE AND CONJUNCTURE}

For a political party, change is never simply a matter of summoning the political will necessary to put the correct formulas into practice. On the contrary, it is a process involving historical baggage, and characterized by conflict and bargaining. In general, transformation of parties is understood in the literature as being caused by electoral environment, a dramatic economic crisis, and such intra-party factors as leadership. ${ }^{2}$ In this case, however, change came in part due to the military coup and the subsequent closing and opening of political parties by the decisions of a junta.

Neither the pre-1980 left nor right could readily embrace the ideas, values, assumptions of neo-liberalism, the dominant paradigm of the 1980s. A free market was alien to their tradition. But, while the ideological baggage of the left was more democracy-friendly, the AP and DYP tradition was more on the side of the state from a conservative and illiberal position. Therefore, attitudinal and legal shifts in post-transitional Turkey 
brought to the fore the tensions, limitations, contradictions, and fault-lines of the Turkish right more so than those on the left. Add to that the fact that as the AP was the senior partner of the coalition government at the time of the military coup of 1980 , the successor party especially suffered the ideological bias built into the transition regime.

The cluster of motivations from global transformations is also central to understanding the DYP's change. The global agenda of marketization narrowed the room for choice and removed the boundaries between old ideological positions. In the 1980 s, private economic power, new ideas built around democracy and quality of life, and social change eroded traditional ties and institutional channels of representation and put pressure on governments. Under this global agenda, social class, though still operating incognito, became an uncertain motive in organizing political life. Ethnic and religious affiliations were advanced by increasingly activist proponents of subcultural identities.

Historically, Turkish political parties were strongly oriented to control their supporters and would-be adversaries through public funds, patronage networks, and an absence of intra-party democracy. ${ }^{3}$ Under these conditions, it was not easy for political parties to address the new electoral trends including, notably, disenchantment with politics, increasing voter volatility, and defections from political parties.

These are global trends and not just peculiar to the Turkish political scene. ${ }^{4}$ The DYP did try to adjust to such changes. With the advent of Tansu Çiller as leader of the party in 1983, the DYP can be said to embrace two such adjustments in response to globally induced electoral trends. The first is the increasing personalization of political representation by individual leaders, expressed by the rise in "personal vote" or "Americanization of political competition." Given that even the leader-shy post-war Italy went through a period in the 1980s of emphasizing the character of the prime minister, particularly Silvia Berlusconi and Romano Prodi, it is not at all surprising to find an increasing incidence of "personal vote" among the voters of a party like the DYP where the leader-based image is stronger than most.

Secondly, and more importantly, Turgut Özal, former leader of the Motherland Party (Anavatan Partisi-ANAP), which was the ruling party of the post-military era from 1983 to 1991, had already emulated the global trend of shifting emphasis from competition and interest articulation to "effective governance." Under Özal ANAP politicized issues that had direct relevance for day-to-day life (e.g., telecommunications, energy, and value-added tax), which had not been given priority by 
the previous governments. As these issues came to dominate the public debate, the language of appealing to the voter was also greatly democratized, moving from an abstract vocabulary to an issue-based concrete, everyday language. Effective governance involved a new kind of policymaking in which elected representatives brought in their own team of experts from outside the bureaucracy as heads of agencies or advisers. In this "political enterpreneurship," the elected politician either appropriates an existing issue or creates a new policy issue and builds his/her own career on its promotion.

Under both Süleyman Demirel and Tansu Çiller, the DYP also adopted the strategy of "effective representation" and "political enterpreneurship" in differing degrees. Çiller turned to solving the Kurdish problem and integration with the European Union (EU) through the Customs Union to promote her "personal" rather than party's support. Her policymaking style, which rested on economic teams and managerial skills, was designed to address the voters' shift of preference for effective governance.

The return to competitive politics in 1983 was shaped by the military's desire to avoid the destructive instability and confrontations of the past, caused, the generals believed, by political actors more interested in selfgain than securing collective interests. The military rulers (1980-83) and the ruling party of the 1980s, ANAP, altered the social bases of politics and the institutional framework for competition ${ }^{5}$ and undermined the power of the old parties and political class. It is important to emphasize that as a result of the depth of the state crisis on the eve of the coup, the armed forces had greater autonomy from the social forces than had previously been the case. The shift to economic liberalism was predicated on the creation of a socially disciplined and depoliticized society. In other words, economic liberalism was promoted through a conservative-authoritarian political agenda. This entailed a new phase of modernization and entry into the global economy and politics.

The process of restructuring the political system unleashed two major dynamics that prevented the DYP from recapturing the leadership of the center-right, which the AP, its predecessor, held in the two decades preceding 1980. The most pressing problem for the DYP was the increased consolidation of the right within ANAP. Ironically, the second problem was the fragmentation of the right beginning with the conspicuous emergence of the DYP in the local elections of 1989. The rise of ANAP as the dominant party of the right was given impetus by the vetoes and bans employed by the military before the first post-coup elections in 1983 in which the DYP was not allowed to run. ${ }^{6}$ In the first half of the 1980 s, the 
DYP's inherited support from the AP thinned, its appeal declined, and its isolation grew. This was due in a real sense to the political engineering of the ruling military and ANAP: the latter tried to prevent the DYP from revitalizing itself and mobilizing its traditional clientele. In a political climate where the ruling elite "exploited the issue of pre-1980 anarchy," the DYP was faced with the difficult prospect of gaining electoral support and legitimacy as true heir of the center-right tradition. While ANAP engendered Turkey's transition into the new economic and international era the DYP remained on the defensive and focused on political survival. The 1989 local elections marked a turning point in the development of the DYP's political profile as it confirmed the trend of fragmentation and increased heterogeneity within the Turkish right. ${ }^{8}$ Yet the DYP managed to increase its 1987 share of the votes by six percent. This generated hopes to capture power through elections and injected self-confidence into the rank and file. Thereafter, the party was able to turn its energies to the goal of defeating ANAP. In order to achieve this it felt driven to articulate an identity distinct from that of its predecessor and not built around a defensive posture. However, this transformation did not prove to be an easy one.

Hüsamettin Cindoruk, an old guard who is a loose cannon but an eloquent speaker, was elected as the party's third leader at its First Congress on May 14, 1985, and stayed in power until the political ban on Demirel was lifted in 1987. Cindoruk was one of the first to voice the need for changes in ideology and leadership practices to gain popular support for the DYP. His suggested proposal for renewal was prompted by "a developed and changed constituency since 1980." His call to end the leader-based structure and develop "a more qualified and intellectual party management" 10 estranged the Demirel die-hards. Cindoruk's appeals were seemingly focused on an organizational reform based on more internal democracy and a changed system of leadership recruitment and decisionmaking. However, since a structural renewal could not be considered independent of a change in ideology and discourse, it was, in fact, a call for a new identity for the DYP.

One central difficulty for the DYP in coming to terms with the dominant paradigm was that its political roots were not liberal, since statism rather than liberalism had been Turkey's historical route toward establishing capitalism. Neither the DP nor the AP was unambiguously liberal. As parties of the periphery, they depended on the most significant cleavage within the existing power balance: between the central bureaucratic elite and the rural periphery. The appeal of both parties was 
similar to that of the Democratic Party of the 1950s, which "was not ideological but ... rooted in the social structure of Turkey." for this core constituency of small peasants and for the rising urban commercial groups was relevant only to a very limited extent. They were organically linked to the state by statist subsidies and protections.

The cold war anti-Communist ideology of the state further reinforced the conservatism of the periphery. The rising Turkish bourgeoisie wanted freedom from the straitjacket of the statist public bureaucracy rather than a liberal state ideally understood as a limited state. The DP and AP tradition incorporated the popular resentment against the State into a basically pro-state discourse. The DP-AP line helped to moderate the center-periphery antagonism by integrating the peasantry and rising business into the circle of populist beneficiaries. The DP's and AP's containment as well as of peripheral elements can be said to have reduced the uncertainties of democratic politics and increase the integrative power of the state.

However, by the mid-1980s there was a sizeable and complex middleclass that questioned these ideas; the members of this class were more individualistic and opposed the state and state-oriented capitalistic development models. As far as they were concerned the DYP's approach was too mild.

\section{DEMIREL'S “TWO-NATIONS” STRATEGY AND IDENTITY ISSUE}

(1991-93)

Being conditioned by its traditional statist and populist outlook and constrained by its ambivalence towards liberalism, the DYP faced serious difficulties in articulating free-market orthodoxy. On becoming the party's leader at the extraordinary general congress of September 14, 1987, Demirel developed a vision that combined two strategies. The first was an attack on the softest flank of the ANAP — its social policy deriving from its free-market approach. The economic reforms of the ANAP governments that shifted from the state's traditional "wealth distribution" to "wealth creation," adversely affected the key social groups. In order to address the dislocating effects of Özal's marketization, the DYP under Demirel revived its state-friendly posture and developed a "social state" discourse directly appealing to its suffering core-supporters, "the other Turkey." The latter was comprised of lower-middle classes, small and medium-sized businesses, and the peasantry, which, after 1980, had turned their backs on the AP's tradition. 
To appeal to "the first nation," the educated urban groups that were not unhappy with the new phase, the party appropriated some aspects of market liberalism and advocated greater democracy, which it accused ANAP of neglecting. It also introduced new, young, and dynamic faces to the party, including Çiller, who had ties to urban and business elements in its bid to broaden its base of support. Demirel called the new formula "combining societalism [toplumculuk] and liberalism." ${ }^{12}$ For Cindoruk it was the adoption of a more egalitarian distribution of economic resources by state dirigisme alongside the commitment to some elements of market economy so that "the public economic enterprises would be used to implement an economic policy with social content." 13

But was it feasible to combine the goal of rolling back the state and discarding populist policies with the goal of reviving the patrimonial role of the state? Realizing the incompatibility of these divergent goals, Demirel was quick to point a way out of this dilemma: the growthinducing potential of the free-market economy paying for the costs of the social services. ${ }^{14}$

The social welfare emphasis of the party reached its culmination with the Election Manifesto of 1991, which combined a commitment to a true market economy with the promise of an extensive list of social welfare provisions. ${ }^{15}$ The party received 27 percent of the votes in the elections in comparison to ANAP's 24 percent. Between the 1991 and 1995 general elections, DYP became the senior partner of a series of coalition governments with the Social Democratic Populist Party, first under the leadership of Demirel and, from 1993 to 1996, under Çiller. However, despite increasing social polarization and declining living standards, the coalition government of the DYP-CHP failed to implement any significant changes in the social policy area to expand its support among pre-1980 core supporters. A complete reversal came with Çiller's state-shrinking discourse, which promised to set up economic liberalism.

Social welfare, democratization, and support for the free market were all designed to build the party's popularity. Democratization referred to anti-militarism, the rule of law, and expansion of political participation. This anti-militarist stance and rhetoric was probably the most radical any political party had adopted in Turkey. It questioned the constitutional role of the National Security Council (Milli Güvenlik Kurulu-MGK) and expressed its concern over the changed power relations between the armed forces and the political class in the former's favor. The party hierarchy demanded the establishment of the principle of civilian control over the military. ANAP was portrayed as "the emanation [kuyruk] of the 
coup, ... using ... the political influence of the military for furthering its political fortunes." 16

Still, Demirel's appeals on this front did not prompt popular support at a time when the military still enjoyed a phenomenal prestige and legitimacy. The restrictive provisions of the 1982 Constitution, which emphasized "the consolidation of the democratic authority of the state," were essentially in tune with the pre-1980 party line. Demirel's fluctuating stance on this issue continued during the later years. In 1990, while he was still in the opposition, Demirel vocally demanded a reorganization of the civil-military relations to establish civilian control over the military as it was the case in the West. ${ }^{17}$ Two years later, as prime minister, he introduced a bill placing the chief of general staff under the minister of defense which was defeated under the vote of his party members in the Parliamentary Defense Commission. The same bill was again rejected eight months later in the same commission by the same members. ${ }^{18}$ The issue of the chief of general staff being accountable to the minister of defense, rather than the prime minister, is of great significance in Turkey for those advocating the establishment of liberal democracy along the lines suggested by the European Union and those who see this type of division of authority as indicative of subordination of the military to the civilian authority along Western lines.

The second pillar of the party's democratization rhetoric was the leader's conversion to a "human rights" emphasis based on the Paris Charter signed on November 21, 1990 under the auspices of the Conference on Security and Cooperation in Europe (CSCE). The party's 1991 Election Manifesto, the Coalition Protocol signed with the Social Democratic Populist Party on November 19, 1991, and the coalition government's program all incorporated this particular theme. The last item of the democratization agenda was the DYP's promise to revise, abolish, or improve domestic laws impeding political participation. It meant the removal of Provisional Article 4 of the Constitution that banned the former leaders and other cadres of the pre-1980 parties from taking an active part in politics for ten years. The strategists of the DYP tried to enlist the support of liberal elements for lifting the political ban on Demirel with the message that "Demirel had changed," 19 but the credibility of this effort was undermined since it was seen as a way to abolish Demirel's own banning.

THE DYP UNDER TANSU ÇILLER (1993-96)

Çiller succeeded Demirel as leader in the Extraordinary Congress on June 13, 1993. Demirel had brought in Çiller to engender the urban sectors' 
confidence in the party by showing that it was truly liberal. What made her accession extraordinary was that she was not only the first woman elected to the leadership of a political party in Turkey, but to a right-wing party where the top cadres were always occupied by male politicians. This was also the case in left-wing parties. To prove his neutrality as the country's President, Demirel refused to follow his predecessor Özal's example of meddling with his party's affairs. But as a party conditioned by the tutelage of a powerful leader since 1964, the date Demirel assumed the leadership of the party, the DYP was driven into confusion by its leader's silence. The expected aspirants to power could not obtain the necessary support and confidence to achieve victory and Çiller was able to slip through the cracks of indecision. She galvanized the imagination of her countrymen and women via the media.

From June 1993 until her social democratic coalition partner left the government and forced her to hold early elections on December 24, 1995, Çiller's stand on party identity and core problems differed from those adopted under Demirel in three senses. First, while Çiller subscribed to economic liberalism in the tradition of Özal; her predecessor's commitment to it was never unconditional. Second, having come to power with a promise of democratization, Demirel could not take a conservative stance on democracy issues. However, as explained below, Çiller took an antiliberal, conservative position with regard to issues regarding the state, individual, civil society, and democratization. Third, contrary to Demirel's cautious and piecemeal policies, Çiller was committed to flagship achievements such as entering the Customs Union and delivering a catastrophic military defeat to the insurgent Kurdistan Workers' Party (Partiya Karakaren Kurdistan-PKK). Her goal was to score a major electoral victory so as to unite the Turkish center-right under her leadership.

By returning to Özal's version of competitive market economy, Çiller seemed to end the historic eclecticism of the DYP manifested in the 1980s by Demirel's embrace of a two-nations strategy. In so doing, she attempted to lift the shadow of Demirel from the party. Although she was expected to be the carrier of a multi-class strategy, Çiller chose to follow a different course, which seemed motivated by an instinct of sheer political survival. She aimed to build a narrower constituency through patronage and discretionary control over public funds.

With Çiller at the helm, the political position of the DYP moved from the center to the center-right. She focused on themes of Turkish nationalism, religion, and culture. The AP had moved to the right in the 1970s in reaction to Communism, but with Communism gone from the list 
of available threats, why did Çiller articulate the same fear-oriented strategy? Was this a sign of ideological crisis in the country or in the party or in both? What were the root causes of this drift?

The reasons for this shift can be bracketed under two headings, one global, the other domestic. ANAP's free-market policies, though limited, brought tremendous volatility to the social base of the center-right. Within ANAP's once-secure constituency of middle classes, the incomes of white-collar workers declined sharply, driving them in even greater numbers into disenchantment and frustration with the status quo. This created conditions conducive to a call for a more disciplined and authoritarian regime to protect the citizens from dislocations of globalism.

On the other hand, sizeable sectors of the population consisting of Turkey's youth, big and medium business, relatively well-off white-collar strata in the cities, and intellectuals were all bubbling with enthusiasm for an improved quality of life to be gained from global democracy and information society. The notions of liberal democracy and individual responsibility for wealth creation continued to gain momentum in the 1990s, but the almost metaphysical essence of the state also dominated their minds. The free-market discourse of Turkish business clashed with economic praxis as it was still dependent on profitable connections with state economic enterprises. It is one thing to accept liberalism as a protection of business's share of an economic pie against labor, but quite another to support a political project when its ideological proposals threaten to dismantle an intricate array of state-business relationships. The same sector demonized the social state as the cause of public deficit and inflationary policies and, at the same time, fed on this inflation to fatten itself.

When we add to this conjuncture the decline in the ideological functions of the parties and the alteration in their social bases, the period pushed the DYP under Çiller to seek more security by moving to a conservative discourse articulated with free-market policies. Moreover, because the context pushed for both change and continuity, this generated ideological and tactical flexibility greater than had been available to Demirel in the past. Indeed, Çiller became renowned for simultaneously subscribing to diametrically opposite positions or embracing incompatible positions. She could be seen to be fully dedicated to integration with the EU, while defying the European standards for democracy.

A sense of need for Çiller's conservative shift was also created by the existence of some tension within the party between her supporters and the die-hard Demirel followers. To emphasize her difference from Demirel without creating large-scale resistance and defections and to maximize her 
personal - if not the party's - chances for political survival, she created an authoritarian system of ruling. Moreover, the large-scale war being waged against the PKK represented a major factor in rendering the party's strategy and rhetoric more conservative. The presence of the religiously oriented Welfare Party (Refah Partisi-RP) and the sympathy of ANAP for traditional values also prompted the rightward drift of the DYP under Çiller. The RP, with a growing power base including the protest vote of those having suffered under competitive market conditions since 1980, was the most serious center-right competitor to the DYP. ${ }^{20}$ Çiller's conservative-populist appeal was also an attempt to recapture those sectors lost to the RP.

In addition, it can be claimed that the disappearance of the Turkish left and the ideological and structural crisis in ANAP also contributed to Çiller's abandonment of political liberalism. As ANAP left behind its earlier emphasis on liberal rights and freedoms, market economy, and limited powers for bureaucracy, the DYP would have no longer lost its supporters to ANAP even if it failed to implement such policies. Not surprisingly, when a democracy package by the coalition government was brought before the parliament on May 18, 1994, deliberations on it became deadlocked. Even for the items passed, right-wing conservatives in the party who lacked the political will to translate the constitutional amendments into reality blocked synchronization between the laws and the Constitution. Çiller's strategic choice at this point was not to push them any further.

Finally, there were the conservatizing effects of Çiller's complete reversal from Demirel's reluctance to embrace the market economy. However, despite her commitment to curb inflation, bring fiscal balance, reduce the high interest rates, and achieve market and public sector reforms, since 1994 was a year of local elections, her administration issued TL21 billion in 15 days. Combined with the volatility in the domestic markets of speculative foreign capital, which financed the economic growth, the economy collapsed nine months after Çiller took over at the helm of the party (January 1994). ${ }^{21}$ A stability package was introduced on April 5, 1994. To cope with the corrosive effects of the distributional deterioration the crisis caused, she turned to an even more conservative approach. The names she placed on the deputy candidate lists she prepared for the 1995 elections consisted of former police chiefs, bureaucrats, regional governors of the state of emergency zone in the southeast, and conservative-nationalist-religious figures whose orientations were totally set against the themes of change she sometimes used. 


\section{THE KURDISH QUESTION AND THE CUSTOMS UNION AS WINDOWS OF OPPORTUNITY}

The escalated war against the PKK and the prospective entry into the Customs Union opened windows of opportunity for Çiller as a political entrepreneur. She began her leadership with a permissive outlook toward Kurdish cultural expressions. During a meeting with Mesut Yllmaz, the leader of ANAP, a month after she became the leader of the DYP and prime minister, Çiller was reported to have suggested broadcasting in Kurdish on the state radio for one hour a week, making Kurdish language an elective course in high schools, and producing civilian solutions to the problem in parliament. When Yilmaz offered to take the issue to the MGK, Çiller responded: "What have issues on domestic politics and foreign policy got to do with the MGK?"22

A month later, she denied any initiatives along these permissive lines. ${ }^{23}$ When she sensed that scoring a decisive military victory against the PKK would help greatly assist her political fortunes, she became the architect of an uncompromising stand with regard to the Kurdish problem that had lasting effects on the quality of Turkish democracy, the economy, and social life. Involving 30,000 security forces and absorbing 20 percent of the national budget, the escalated scale of the armed conflict exacerbated a chronic inflation and helped set the precedence of security forces collaborating with ultra-nationalist crime syndicates to hunt down the PKK sympathizers.

Connected with the Kurdish problem, Çiller's approach to the military represented a radical departure from the traditional party line. As she hoped to score a political victory on the Kurdish issue by a military gain, she abandoned any pretense of supporting civilian control over the military. Indeed, Çiller refrained from undertaking any initiative that would displease the high command and, instead, endorsed their wishes on any issue. Doğan Güreş, the chief of general staff who was later elected as deputy on the DYP ticket (1995), has reiterated the accord between his prime minister and the high command: "The armed forces has regard for the prime minister because she acts like a tiger. I worked with ease with all prime ministers, with Özal, Akbulut, Yılmaz, and Demirel. But with Çiller I worked with more ease." ${ }^{24}$ The result was that the civilian initiative on the Kurdish question was relegated to the sidelines. Moreover, while the defense and security expenditures rose to 17.3 percent of the 1996 budget, the ratio for education was half of that figure and health spending was three-four percent. ${ }^{25}$

Similarly, after the historic signing of the Customs Union with the EU 
countries on March 6, 1995, which formalized further economic integration between the EU and Turkey, the troubled coalition government between the DYP and its social democratic partner came to an end on September 20, 1995. Çiller launched her election campaign on the issues of Turkey's membership of the Customs Union and her unflinching struggle against Kurdish separatism. Mindful of her domestic failures on many issues, Çiller referred to the union with the EU as the crowning achievement of her term in office and projected an image of "greater Turkey" stretching from the Balkans to the Transcaucasus and acting as the locomotive for the Middle East. This, she thought, would lead to a political union between Turkey, Bulgaria, and even Romania, capable of solving the Balkan problem. ${ }^{26}$

Another issue she campaigned on was the abuse of religion by the Welfare Party (RP) for its own political and economic interests: "They have maintained their political supper by exploiting religion ... the more Turkey is distanced from Europe and pushed into loneliness and Middle Easternized, the more these people could act with success. ${ }^{27}$ In stark contrast to her vocation of integrating with Europe and despite her strong attacks on the RP that went so far as accusing the party of collaborating with the PKK, ${ }^{28}$ she formed a coalition government with the RP on June 28, 1996, with the RP's leader as prime minister and herself as deputy prime minister and foreign minister. The forging of this coalition was the beginning of the party's and the leaders' debacle.

\section{REFAHYOL COALITION: \\ DEMISE OF THE LEADER AND THE PARTY}

The Refahyol era (the popular name for the DYP-RP coalition) ended in disaster for both coalition partners when, on February 28, 1997, the MGK handed the government a list of measures to clamp down political Islam, causing its eventual resignation. ${ }^{29}$ At first sight, it seems that the breakdown, defeat, decline, and humiliation of the DYP, Çiller, and the political system were precipitated by the Turkish political leaders' "style of power holding," which was characterized by short time horizons, lack of self-confidence and trust in their political base, and an unscrupulous mode of promoting political rent-seeking networks. On the other hand, a political class threatened by the formal and informal role of the military as the ultimate guardian of the regime has critical problems in relinquishing patronage resources. In that guardianship model, the political class constantly weighs the political pay-off derived from a reform in the 
system - to put an end to powerlessness, incapacity, corruption and stasis - against the costs of giving up power based on patronage. It is more than likely that the civilian political class will not choose to terminate the rent-seeking networks by reforms that would reduce the prominence of military in politics. Its foremost concern will be a short- rather than longterm one.

Precisely the same motives were at work in Çiller's and Erbakan's drive toward Refahyol. Çiller needed the RP's support against corruption inquiries tabled in the parliament against her, ${ }^{30}$ while the RP's leader Erbakan wanted to reap the benefits of being in power by building his own patronage network. The Refahyol episode today impedes the effective functioning of the party, having delivered a deadly blow to the secular and modern, Western-oriented image the DYP had been trying to develop for itself since 1991. Çiller's personal integrity, leadership style, character, family, entourage, and the sources of her wealth also came under close scrutiny, causing a further decline in public support for the party. There were resignations and defections, ending up in the formation of the Democratic Turkey Party (Demokratik Türkiye Partisi-DTP). ${ }^{31}$ By forming a coalition government with Erbakan, renowned for his rentdistributing tendencies, Çiller tarnished her image of having a commitment to a free-market program, her only claim to legitimacy and popularity in the absence of her engagement with political liberalism.

The DYP's earlier harmonious relationship with the military also changed radically after the Refahyol experience. Çiller made a complete U-turn from a position of regarding the armed forces as the best guarantor of democracy, ${ }^{32}$ to challenging the military's role in safeguarding secularism on the basis of popular sovereignty and "national will." At some point, she even built up "her own" civilian security forces within the ministry of interior.

The military's consequent wrath against Çiller was serious and the struggle between them took the character of life and death. ${ }^{33}$ The High Command and Çiller exchanged harsh words daily. Çiller stated, "Turkish people love and trust their army. But this trust is bestowed on them not as politicians, but as soldiers ... for control in democracies is in the hands of parliament. It is not in the hands of those outside the national will." ${ }^{34}$ The military's spokesman responded the same day by saying, "Çiller is like a sinking ship ... It is Çiller who emboldens the reactionary forces ... The Turkish armed forces enforce a constitutional duty to protect the secular democratic Republic. It is always above politics and subscribes to democracy." 35 
The most profound damage Refahyol inflicted on the DYP's image was to bring the most unprincipled and unreliable aspects of the leader's political profile into the limelight. Çiller suffered most with regard to her "credibility" as a person and as a leader. This stemmed from the discrepancy between her 1995 election campaign, which was based on lashing out against the RP, and her subsequent behavior. Although by 1997 Çiller was already known for false statements aimed at self-promotion, the fear and insecurity combined with her growing insecurity during Refahyol drove her to pronounce statements that she could not substantiate and promises she could not fulfil. ${ }^{36}$

\section{LEADERSHIP AS LIABILITY IN THE NEW MILLENNIUM}

The tradition of the leader's iron control on and total autonomy from the rank-and-file members has underpinned the operation of the Turkish political parties. Deregulation, considerable liberalization in the market, privatization, and abandonment of protective restraints in the economy since 1980 have not weakened leaders' absolute hold over the patronagebased intra-party support networks. A key component of this leadership style has been the monopoly power to impose her/his will over deputy candidate selection so as to bring any potential dissidence within the party under control and deter would-be challengers. Another common element explaining unquestioning obedience to the leader is the supply of politicians who grow up with a culture of clientelism and leader worshipping so that in their eyes even the mildest crticism of the leader is either illegitimate or unthinkable. If there are serious challenges based on discontent in the party, the views are almost always articulated ambiguously and timidly. In any case, there is usually no consensus over an alternative leader.

Çiller retained power in the party through similar tactics that ranged from cooptation to divide-and-rule and expulsion. In the minority government she formed on October 6, 1995, which failed to receive a vote of confidence, she gave eight ministerial posts to her ardent critics in the party. Cindoruk, the former party chairman and speaker of the parliament remarked, "It becomes clear that there is no organized opposition to [Çiller] because the colleagues who claim to oppose her rushed to accept cabinet posts." ${ }^{37}$ Equally effective was her strategy of "divide and rule." During the Refahyol government, when she faced the most difficult time of trying to quell the disquiet in the party, she weakened a faction by excluding the leader but including his followers in the party's top policymaking body. ${ }^{38}$ When it came to coping with potential challengers for her seat, like Yalım Erez and Cindoruk, Çiller opted for expulsion. Mass 
expulsions were also resorted to at the provincial level to ensure that Çiller sympathizers were elected as delegates to the national convention. ${ }^{39}$

As a result, the essential element in this heavily patronage-based system, which enabled Çiller to sustain her power without serious challenges, has been that those seeking to keep or advance their careers knew they must be on good terms with the leader who controls access to the coveted state resources. After falling out with Çiller over the leader's responsibility for reduced electoral support following the 1999 elections, Meral Akșener, Çiller's long-time confidante and former minister of interior, explained that there was no internal critique of her leadership despite widespread disaffection because: "Decisions were imposed on us. Nobody could risk being the black sheep. If you didn't agree with the decision, you kept silent ... The biggest problem of the DYP was insecurity and fear." ${ }^{40}$ While Akșener characterized this state of affairs in the party as "crony democracy," Ünal Erkan, a former regional governor of the southeast and a one-time favorite of the leader, described Çiller's leadership style as "sultan like," meaning its personalistic and authoritarian nature. ${ }^{41}$

The most serious challenge to her leadership came in the National Congress on November 20, 1999. This Congress was regarded as critical for the party and the leader after they had suffered their worst electoral defeat in the April 1999 elections, scoring an all-time low of 12 percent. It was impossible for the party members not to be affected by the intense anti-Çiller public sentiment that held her responsible for having pulled the party into a dangerous game with the Islamist Welfare Party. As it was widely believed that Çiller's and Erbakan's parties would no longer be entrusted with executive power by the military even if they scored sufficient electoral victories, both parties fell into an ineffective existence.

Çiller decided to use this crisis as an instrument to recover her popularity, achieve a comeback, and ward off the threat of a take-over by her opponents in the party. Thus, to prevent the supporters of possible challengers from attending the Congress, she embarked on a massive and relentless campaign to dismiss all provincial level party officials who were against her. Furthermore, her opponents were again split, unable to agree on a common candidate and kept up bickering among themselves ${ }^{42}$ As a result, Çiller won the leadership again.

\section{A WAY OUT OF PARIAH-PARTY STATUS (1997-2001)}

After the February 28, 1997, MGK initiative, the DYP's image disintegrated alongside that of the leader's. It also suffered from the loss of support by opinion makers, newspaper editors, and television journalists. Its 
ineffectiveness in influencing the public debate and policymaking process was exacerbated by its own sense of weakness. The leadership adopted a platform of support for democratization and reform to recover from the pariah-party status and to counter the military. This was reminiscent of the post-1960 AP's emphasis on political freedoms and "national will" over the military's will in order to develop a power base from the ruined image of the Democratic Party. This new line highlighted the fact that in Turkey it is only when a political party is in opposition it becomes a champion of democracy, the rule of law, and major political change.

Similarly, when she fell into opposition in June 1997, Çiller too turned to these issues in order to survive the defeats the party suffered since February 1997. She argued that her party had put priority on economic liberalism and struggle against terrorism when in power and, consequently, it could not pay attention to the problem of political liberalization. ${ }^{43}$ In a further effort to legitimize this omission, Çiller connected democracy with a robust economy. ${ }^{44}$ She suggested that the small and medium-sized holdings her 1991-93 administration promoted would help provide the economic prerequisite for a stable liberalism to flourish.

The reforms listed in the "Second Democracy Surge," package was called at the time, contained three elements. First, just as after the post-1980 coup, "national will" and "supremacy of the parliament" became the bases of an anti-militarist posture. Second, the new democratization program focused on the official ideology of the state, which Çiller now considered an impediment to democracy. ${ }^{46}$ The third was free-market economy.

Çiller did not fully apply a free-market strategy when in government. Faced with the realities of coalition politics, which required concessions, and with fear of losing electoral support, she attempted to change the fundamental parameters of state-economy relations, but nevertheless continued the populist policy of income transfer. However, compared to Demirel's social state welfare policies, her engagement with distributional state policies was more reluctant, less systematic, and more a transitional phase, while her commitment to free-market orthodoxy was far stronger. Under her administration, which shared power with Social Democrats from 1993 to 1995, Turkey's political atmosphere was marked by a moderate optimism with regard to the continuation of market-oriented economic policies, without the extremes followed by Özal's marketization. By 1996, however, there was no economic policy to speak of. From then on all Çiller's efforts concentrated on retaining power by whatever means were available. 
The chief paradox was the irreconcilability between her emphasis on democracy and the excessively conservative and authoritarian policies. By steadily moving in a religious-nationalist direction, it was hoped that the party would attract some disaffected voters from the RP and the Nationalist Action Party. However, the April 1999 elections illustrated the fallacy of this assumption. Perhaps the most deadly blow to the credibility of this democracy campaign that revealed her administration's unsavory practices was the scandal that emerged in the aftermath of a road accident on November 6, 1996 in Susurluk, a small township in northwestern Turkey. This scandal revealed the existence of a criminal triangle of politicians, mafia bosses, and security forces engaged in the war against the PKK. ${ }^{47}$ As the public outcry turned into an immense societal pressure to reform the justice system, police, and bureaucracy, Çiller's DYP was among those that opposed a "clean hands" operation to secure transparency in the system. Çiller gave unequivocal support to dubious state practices involving illegal murders: "Those who shoot bullets or those who are the targets of bullets in the name of the state are both honorable. They all are heroes." ${ }^{\prime 48}$

The dilemma that the DYP faces lies in the party leadership's failure to understand the changing political and social reality in Turkey and all over the globe. Despite Çiller's attempt to respond to the demand for effective representation by developing a model of political enterpreneurship, by and large the party leadership still considers politics as influence-peddling, patronage distribution, and the making and breaking of coalition governments. The fact that governments continued to be formed according to electoral results misled the politicians of the late 1990s into thinking that parties could continue to operate much as before without change. More importantly, democratization is considered a process that is completed when the leader holds a press conference and reads out a long list of promises of political reforms. ${ }^{49}$ Among other things, bottom-up democracy is not envisaged outside the traditional party machines and in non-electoral areas.

Policy issues such as political violence, massive internal migration, the new faces of urbanization connected to the southeast question, global capitalism, the military's political autonomy, and the media's new role in shaping culture and society are not thought to be worth looking into despite the fact that they underpin the workings of the party. Political debate revolves around simpler matters, like comparing current prices of goods to those prevailing under the previous DYP government as "proof" of that party's superiority. ${ }^{50}$ The DYP, like other parties, talked extensively 
about comprehensive reforms after the February 2001 economic collapse. It was perhaps the only party that specifically called for the reform of the Political Parties Law to end the leadership tutelage in the parties, as a starting point before new elections are held. However, it is doubtful whether the party possesses the willingness or ability, and whether the leader has enough credibility to take such steps.

The rules of the political reality in Turkey underwent major changes in the 1980s and 1990s, but the DYP has been unable to adjust to this situation. How could a political party born and bred in a heavily statecentered political environment control government expenditure and build social peace in the face of a widening gap in the distribution of income, especially acute for its core base of small and medium-farmers? How again could it bow to a massive global inflow of capital without hurting its chances of winning the battle against inflation faced by the lower-middle classes? Defeated at the polls and humiliated by the February 28 process, the party tries to make a comeback based on the February 2001 economic crisis. Yet, in all probability, the party's flaws - or at least those of the Çiller leadership - cannot be overcome even in the face of such a potential opportunity for the opposition at a time when the problems are so great and those in power are so heavily criticized.

\section{NOTES}

1. This contribution draws on some ideas presented in Ümit Cizre, "Liberalism, Democracy and the Turkish Centre-Right: the Identity Crisis of the True Path Party," Middle Eastern Studies, Vol.32, No.2 (April 1996), pp.142-61); and idem, "Tansu Ciller: Lusting for Power, Undermining Democracy," in Metin Heper and Sabri Sayarı (eds.), Political Leaders and Democracy in Turkey (Lanham, MD: Lexington Books, forthcoming).

2. Angelo Panebianco, Political Parties: Organization and Power (Cambridge: Cambridge University Press, 1988), pp.242-6.

3. For a brief historical account of some important maladies of the Turkish party system until 1995, see Ergun Özbudun, Contemporary Turkish Politics (Boulder, CO: Lynne Reinner, 2000), pp.73-103.

4. Klaus von Beyme, "Party Leadership and Change in Party Systems: Towards a Postmodern Party State?," Government and Opposition, Vol.31, No.2 (1996), pp.135-59.

5. İlter Turan, "Political Parties and the Party System in Post-1983 Turkey," in Metin Heper and Ahmet Evin (eds.), State, Democracy and the Military: Turkey in the 1980s (Berlin and New York: De Gruyter, 1988), pp.63-80.

6. The DYP faced a series of vetoes by the military rulers within 78 days from its foundation. Fifty-seven of its 88 founding members and one leader were vetoed. Worse still, although by July 22, 1983 it was able to pass the required threshold of 30 founders by one, through the deliberate delaying of the Council of National Security (the transitional body set up to execute the military's policies until the transition to civilian rule in 1983) to endorse the list, the party was precluded from running in the 1983 elections.

7. Süleyman Demirel, DYP 2. Büyük Kongresi Açış Konuşması (Ankara: n.p., 1988), p.29.

8. The DYP and ANAP received 25.1 and 21.8 percent of votes respectively. Two of the parties on the right, the pro-Islamic Welfare Party and the ultra-nationalist Nationalist Work Party, 
scored 9.8 and 4.1 percent of votes, respectively, representing a 2.7 and a 1.2 percent increase from the previous elections though they were unable to pass the threshold. By entering into an electoral alliance, the two parties were able to win 16.7 percent of the votes in the 1991 elections.

9. Nokta (Istanbul weekly), May 29, 1988, p.18.

10. Ibid.

11. W.B. Sherwood, "The Rise of the Justice Party in Turkey," World Politics, Vol.20 (1968), p.55.

12. Süleyman Demirel, “Artık Demokrasiler Tezsizdir," in Hıdır Göktaş and Ruşen Çakır (eds.), Vatan, Millet, Pragmatizm-Türk Sağında İdeoloji ve Politika (Istanbul: Metis Yayınları, 1991), p.21.

13. "Cindoruk'la Sol, Sağ ve Militarizm Sorunu," Yeni Gündem (Istanbul weekly), June 15, 1985.

14. Doğru Yol Partisi Genel Başkanı Süleyman Demirel'in Basın Toplantısl, Oct. 1, 1991.

15. 21 Ekim Sabahı Yeni Bir Turkiye-Seçim Bildirgesi, 1991.

16. Süleyman Demirel, Türk Demokrasisi Meydan Okuyor (Ankara: DYP Basin ve Propaganda Başkanlığı), p.133.

17. Süleyman Demirel, “12 Eylül Vaadleri Tutulmadı,” Milliyet (Istanbul daily), May 28, 1990. In this interview Demirel openly stated, "In Turkey, the place of the chief of general staff is, in fact, above the minister of defence. Is Turkey a military republic? ... The place of the chief of general staff should in fact be below the minister of defence ... In which country in the world, every week the chief of general staff sees [the] president and gives briefings to him?"

18. See Hürriyet (Istanbul daily), Jan. 15, 1993.

19. Mehmet Ali Birand, "Demirel Çok Kişiyi Utandıracak," Milliyet (Istanbul daily), Sept. 6, 1991.

20. The RP scored the largest increase of votes ( 9.2 percent) among the Turkish political parties between the 1989 and 1994 local elections.

21. "Hoș Geldin Seçim Ekonomisi," Hürriyet (Istanbul daily), Jan. 19, 1994; Güneri Civaoğlu, "Kara Çarșamba," Sabah (Istanbul daily), Jan. 20, 1994; Enis Berberoğlu, "Lira Katili Ayağa Kalk," Hürriyet, Jan. 19, 1994; and Erdal Sağlam, “Bunun Adı Stagflasyon,” Hürriyet, Dec. 7, 1994.

22. Sedat Ergin, "Çiller ve Ordu Hükümet İlişkisi," Hürriyet (Istanbul daily), Nov. 18, 1993.

23. Sedat Ergin, "Kürt Sorununda Kendisinin Bile Gerisine Düștü," Hürriyet (Istanbul daily), Aug. 18, 1994.

24. Interview with Doğan Güreş by M. Ali Kışlalı, "Güreș: Ordu Darbe Yapmaz,” Türkiye (Istanbul daily), Nov. 27, 1995.

25. "Merhaba Asker," Hürriyet (Istanbul daily), Jan. 28, 1995.

26. Tansu Çiller, Türkiyem (publisher and date unspecified. However, it is widely known that the book was prepared and published by the prime minister's office two months prior to the December 24, 1995 general elections), p.110.

27. Ibid., pp.90-91.

28. Ibid., p.153.

29. The ultimatum consisted of a 20-point list of measures ranging from tighter restrictions on religious dress in public places to banning Islamic broadcasting channels, Koran courses, Islamist organizations and asking the government to pass a new bill to extend compulsory primary school education from five to eight years. On June 18, 1997, Çiller persuaded Erbakan to resign in order to soften the military's reaction against the government and have the premiership transferred to herself. However, President Demirel called the game off by asking Mesut Yilmaz, the leader of the rival center-right party ANAP, to head the new government consisting of ANAP, Democratic Left Party and the Democratic Turkey Party (Demokratik Türkiye Partisi-DTP, a splintered party from the DYP).

30. The two parliamentary inquiries concerning Çiller had already been initiated in April and May 1996 by the ANAP (with which the DYP formed a coalition government in the aftermath of 1995 elections on March 3, 1996, which lasted for four months) and the RPP. On June 1996, the ANAP and the RP and the two center-left parties co-operated in another motion, which was tabled to investigate Çiller's wealth. After the formation of the Refahyol government, these motions were defeated by the RP's defection to Çiller's side. 
31. The defectors, led by the old guard İsmet Sezgin and joined by such prominent names as Emre Gönensay, Yalım Erez (Çiller's mentor), Necdet Menzir, and Yıldırım Aktuna formed the Democratic Turkey Party in Jan. 1997, under the chairmanship of Hüsamettin Cindoruk.

32. In an interview with Mehmet Barlas on TGRT TV Channel on Feb. 22, 1997, Çiller openly stated: "Our army can do the civilianization and democratization very well." Excerpts from this interview were published the next day in Istanbul daily Türkiye.

33. Yavuz Gökmen, Sarışın Güzel Kadın (Istanbul: Doğan Kitapç1lı, 1999), pp.124, 150-52, 160-61.

34. Ahmet Sever and Barçın İnanç, "Çiller Orduya Çattı," Milliyet (Istanbul daily), June 28, 1997.

35. Yusuf Özkan, “Genel Kurmaydan Çillere Jet Yanıt,” Milliyet (Istanbul daily), June 28, 1997.

36. For instance, when she spread the rumor that the military supported her mainly because the United States was behind her and that the real target of the military was not her but the RP, the commanders immediately denied it. While she tried to convince Prime Minister Erbakan to transfer his office to her, she simultaneously sought the active support of the military. However, the military indicated that this was the business of parliament. After a while the commanders decided not to have any interaction with her. See Sedat Ergin, "90 Sicak Günün Hikayesi: İmza Sorunu Krize Dönüşüyor,” Hürriyet (Istanbul daily), Aug. 27, 1997.

37. "Cindoruk, Muhalefet Organize Değil," Hürriyet (Istanbul daily), Oct. 8, 1995.

38. Ayvaz Gökdemir was the leader of the group. Ünal Erkan, Cihan Paçacı, and Osman Cilsal joined forces with Gökdemir but were brought to the General Executive Board. See Sebnem Güngör, "DYP Bölünme Eşiğinde,” Yeni Yüzyll (Istanbul daily), July 23, 1996.

39. Between 1996 and 1999, Çiller expelled 65 of the existing 80 elected party heads of provinces. In Istanbul, 126,000 registered members of the party have been expelled. See Bilal Çetin, “Eski DYP'lilerin Yuvaya Dönüş Hazırlı̆̆ı,” Milliyet (Istanbul daily), June 23, 1999.

40. Ercüment İş̧leyen, "Akșener: Çiller Yalancı," Milliyet (Istanbul daily), July 28, 1999.

41. "Erkan, 'Çiller Padișah Gibi'," Radikal (Istanbul daily), Jan. 9, 1999.

42. The strongest candidates for leadership in the Congress were the two senior members, Necmettin Cevheri and Köksal Toptan. A third candidate was pro-Demirel Mehmet Dülger. By November, they disagreed on who would declare his candidacy, when, and how. In the end, Cevheri withdrew his name from the race and Toptan and Dülger became the two contestants, unable to agree which should be the proposed candidate.

43. Taha Akyol, "Çiller’in Penceresinden," Milliyet (Istanbul daily), Aug. 16, 1997.

44. Ibid.

45. "The First Surge of Democracy" is expressed as the ascent of the DYP in 1946. See the 2. Demokrasi Konuşmaları leaflet (publication details unidentified), which became the blueprint for the 1999 elections.

46. Perihan Çakır, "Çiller'den İmam Hatip İtirafı,” Milliyet (Istanbul daily), Aug. 16, 1997.

47. One of the passengers who died was Abdullah Catli, an ultra-nationalist involved in political killings in the 1970s and who was on the run. The others were a civilian security chief in Istanbul and a young woman taken for a joy ride. The only survivor was a tribal chief from the southeast who was also a DYP deputy and whose tribe was on the side of the state.

48. This was hardly a surprising statement as it is now known that she and her then Police Chief, Mehmet Ağar, had been involved in this triangle since 1995, when Ağar had agreed to arrange to hunt and eliminate Abdullah Öcalan, then leader of the PKK, so as to enable Çiller to capitalize on the event for the Dec. 1995 elections.

49. See 2. Demokrasi Konuşmalart.

50. DYP Grup Başkanı Prof. Tansu Çiller 'in 2000 Yılı Bütçesinin Kapanışında Yapmış Oldukları Konuşma, Dec. 28, 1999, <http//:www.dyp.org.tr>. 